\title{
Are there de jure objections to Mādhvic belief?
}

\author{
Akshay Gupta \\ Faculty of Divinity, University of Cambridge, Cambridge, Cambridgeshire, CB3 9BS, UK \\ Corresponding author: Akshay Gupta, email: ag2095@cam.ac.uk
}

(Received 28 February 2021; revised 25 June 2021; accepted 28 June 2021)

\begin{abstract}
Recently, Erik Baldwin and Tyler McNabb have brought Madhva's epistemological framework into active dialogue with Alvin Plantinga's religious epistemology and have argued that individuals within Madhva's tradition cannot make full use of Plantinga's epistemology, according to which, Christian belief resists de jure objections and can also have warrant. While I do not contest this specific claim, I demonstrate that an analysis of Madhva's epistemological framework reveals that this framework has its own resources through which it can resist de jure objections. I address various objections to the rationality of Mādhvic belief and conclude that there are no de jure objections to Mādhvic belief that are independent of de facto objections.
\end{abstract}

Keywords: reformed epistemology; Mādhva; warrant; Alvin Plantinga; Vedānta

\section{Introduction}

The Mādhva Vedānta tradition (henceforth Mādhva tradition), which is a Vaișnava ${ }^{1}$ trad- $^{-}$ ition that is based on the life and the teachings of Madhva (c. thirteenth century $\mathrm{CE}$ ), engaged extensively with, and contributed to, the systems of soteriological practice and philosophical inquiry known collectively as Vedānta. The Mādhva tradition is well known for its opposition to the Advaita Vedānta tradition, which was systematized by Śankara (c. ninth century $\mathrm{CE}$ ). Advaita put forth the thesis that each finite self ${ }^{2}$ is not ontologically distinct (advaita) from brahman, ${ }^{3}$ or the ultimate reality, which is conceived of by Śankkara as being non-personal or without attributes (nirguna). In contrast to Śankara, Madhva endorsed a type of dualism (dvaita), which maintained that brahman, who is identified with the supremely personal deity Vișnu, is wholly ontologically distinct from selves, though each self is dependent on Viṣnu and is a reflection (pratibimba) of him. In fact, according to Madhva's doctrine of 'five differences' ( pañca-bheda), (1) God is ontologically distinct from selves, (2) God is ontologically distinct from material objects, (3) selves are ontologically distinct from material objects, (4) selves are ontologically distinct from other selves, and (5) material objects are ontologically distinct from other material objects.

The ultimate soteriological aim of selves, according to the Mādhva tradition, is to cultivate single-minded bhakti (devotion) toward Viṣnu by hearing (śravaṇa) about him, contemplating (manana) him, and meditating (dhyāna) on him until their love for him fully matures. When selves have fully developed mature love for Viṣnu and have completely 
exhausted their karmic residues, they attain liberation (mokșa) from the world and enjoy a blissful life in the presence of Viṣnu.

Recently, Erik Baldwin and Tyler McNabb have brought Madhva's epistemological framework into active dialogue with Alvin Plantinga's religious epistemology (Baldwin and McNabb (2018), 112-135). Baldwin and McNabb concluded that Mādhvas ${ }^{4}$ cannot make full use of Plantinga's religious epistemology (Baldwin and McNabb (2018), 131132), according to which, Christian belief resists a type of objection known as the de jure objection and can have warrant, which, in sufficient quantity, turns a true belief into knowledge. I do not contest Baldwin's and McNabb's specific claim that Mādhvas cannot utilize Plantinga's religious epistemology. However, I argue that Mādhvic belief, ${ }^{5}$ though structured by an epistemological framework that is different from that of Plantinga's notion of Christian belief, is in a similar epistemic boat as this latter belief there are no de jure objections to it that are independent of de facto objections.

\section{De jure objections to theism and the notion of warrant}

Before defending my above claim, however, it is first necessary for me to distinguish between a de jure objection and a de facto objection. A de facto objection claims that the belief in question is false. For example, one common de facto objection against the existence of an all-powerful, all-knowing, and all-good supremely personal God is the problem of evil.

While the de facto objection against a theistic belief is concerned with the ontological status of God's existence, a de jure objection against a particular theistic belief is an epistemological objection that focuses on the justification and the rationality of that belief. For instance, examples of de jure objections against Christianity would be that one cannot have a proper justification for Christian belief or that there is insufficient evidence for a Christian to rationally accept the existence of God.

A de jure objection to theistic belief is significant because it claims that theistic belief is irrational regardless of whether it is true or false. For instance, one could put forth the following de jure objection to Christian belief.

1. Even if Christian belief were true, one could not acquire a justification for it.

2. Without a justification for a belief, it is irrational to hold that belief.

Therefore, even if Christian belief were true, it would be irrational to hold it.

In his groundbreaking Warranted Christian Belief (2000), along with the companion volumes Warrant: The Current Debate (1993a) and Warrant and Proper Function (1993b), Plantinga argued that there are no de jure objections to Christian belief that are independent of de facto objections. In other words, Plantinga argues that in order to demonstrate that Christian belief is irrational, one has to demonstrate that it is false. While it is beyond the scope of this article to delineate all the steps that Plantinga takes in order to draw this conclusion, I will briefly summarize his reasoning.

In Plantinga (1993a; 1993b; 2000), Plantinga discusses the concept of warrant, which is to be distinguished from mere justification because as Edmund Gettier (1963) famously argued, knowledge requires more than merely having a justified true belief. Hence, for Plantinga, knowledge is a warranted true belief.

More concretely, Plantinga argues that a belief $\mathrm{B}$ is warranted if:

(1) the cognitive faculties involved in the production of B are functioning properly...;

(2) your cognitive environment is sufficiently similar to the one for which your cognitive faculties are designed; (3) . . . the design plan governing the production of the 
belief in question involves, as purpose or function, the production of true beliefs. . ; and (4) the design plan is a good one: that is, there is a high statistical or objective probability that a belief produced in accordance with the relevant segment of the design plan in that sort of environment is true. (Plantinga (1993b), 194)

Plantinga also posits the existence of an epistemic faculty or cognitive mechanism known as the sensus divinitatis (sense of divinity), which, in a variety of circumstances, produces in humans beliefs about God (Plantinga (2000), 167). Individuals in whom the sensus divinitatis is properly functioning (it can fail to properly function in certain individuals due to the noetic effects of sin) may come to acquire beliefs such as 'God is disappointed with me' when ridden with a sense of guilt or 'God's craftsmanship is wonderful' when looking at a beautiful sunset (ibid., 175-176). The crux of Plantinga's argument in his trilogy on warrant is that if Christian belief is true, then we probably have something like the sensus divinitatis, through which Christian belief is warranted (ibid., 285).

Notably, Plantinga does not actually state that Christian belief is true, and in fact, he states that it is beyond the competence of philosophy to answer this important question (ibid., 499). However, while Plantinga does not, through philosophical reasoning, draw a definite conclusion about the truth of Christian belief, he does, in his view, establish that there are no de jure objections to Christian belief that are independent of de facto objections (ibid., 498).

Plantinga also responds to various defeaters ${ }^{6}$ for Christian belief, such as the problem of evil and the claim that it is irrational to accept Christian belief in the face of religious pluralism (ibid., 358-499). After putting forth what he takes to be defeaters for these defeaters, Plantinga argues that it is epistemically possible that Christian belief is rational because it is logically possible, warranted-if-true, and undefeated by defeaters. ${ }^{7}$

It is worth emphasizing that there are two primary components to Plantinga's epistemology. First, (a) Plantinga argues that there are no de jure objections to Christian belief that are independent of de facto objections. Second, (b) he argues that there are no successful de facto objections to Christian belief. Moreover, although both (a) and (b) are important for Plantinga's religious epistemology, the bulk of the warrant trilogy is devoted to defending (a).

\section{Baldwin and McNabb's critique of Madhva's religious epistemology}

Having briefly outlined Plantinga's notion of Christian belief and key concepts like de jure objections and warrant, I now turn my attention to Baldwin's and McNabb's specific critiques of Madhva's religious epistemology. First, Baldwin and McNabb argue that in order for a religious tradition to be able to utilize Plantingian religious epistemology, it must

1. Have a conscious and intentional designer,

2. Have the conscious and intentional designer's nature and past actions be compatible with Plantinga's truth-aimed conditions, and

3. Have a design plan that doesn't depend on there being an actual infinite (McNabb and Baldwin (2016)).

Baldwin and McNabb defend (1) and (2) elsewhere, and it is not necessary to elaborate upon these defences (Baldwin and McNabb (2018), chapters 2 and 10). However, it is worth highlighting that they defend (3) on the grounds that an actual infinite cannot exist and leads to contradictions (although it is worth noting that they acknowledge that the debate about actual infinities has not been settled) (ibid., 125-127). This point is important because as Baldwin and McNabb point out, Mādhvas are committed to the existence of 
an actual infinite, namely, an infinite number of cosmological cycles in which our faculties are formed (ibid., 126). Although the Mādhva can respond to this claim by stating that their design plan is, in fact, dependent on Viṣnu and not an infinite series of cosmological cycles, Baldwin and McNabb maintain that Madhva's religious epistemology nevertheless involves a type of metaphysical dependence on an actual infinite given the development of human cognitive faculties and the history of their design plan (ibid., 127). For this reason, Baldwin and McNabb argue that insofar as this kind of metaphysical dependence is problematic, a Mādhva cannot make use of Plantinga's religious epistemology (ibid.). We can note that Baldwin and McNabb make two claims concerning the existence of actual infinites. Their first claim is that (i) an actual infinite cannot exist, and their second claim is that (ii) metaphysical dependence on an actual infinite is problematic. It is worth pointing out that (i) can be false while (ii) is true. In other words, even if an actual infinite could exist, it can still be the case that metaphysical dependence on such an actual infinite would still present problems. For this reason, even if the Mādhva can defend the existence of an actual infinite, further argumentation is required to show that metaphysical dependence on this actual infinite is not problematic. Hence, according to Baldwin and $\mathrm{McNabb}$, in the absence of such argumentation, the Mādhva cannot utilize Plantinga's religious epistemology, and thus they cannot claim that there are no de jure objections of Mādhvic belief that are independent of de facto objections.

Baldwin's and McNabb's second critique of Madhva's religious epistemology is that even if it could utilize Plantingian epistemology, it would still have a defeater because Madhva's theological framework holds that there are certain selves who are destined to end up in the darkness of hell and whom God does not choose to save (ibid., 127-129). According to Baldwin and McNabb, this fact implies that God does not love all persons unconditionally; however, according to them, it is strongly intuitive that a perfect being loves all persons unconditionally. For this reason, Baldwin and McNabb argue that Mādhvic belief has a defeater because the Mādhva's claim that Viṣnu is a perfect being is jointly inconsistent with the fact that Viṣnu allows certain selves to be damned (ibid., 129). It is important to note that this second critique is best characterized as a de facto objection, and it is not an argument against Madhva's epistemology per se, but rather, his theology.

Thus, to summarize, there are two main objections to Mādhvic belief raised by Baldwin and McNabb. The first is that it is questionable whether or not it can be said that there are no de jure objections to Mādhvic belief that are independent of de facto objections. The second is that there are de facto objections against Mādhvic belief. In this article, I am primarily concerned with responding to this first objection. I argue that there are no de jure objections to Mādhvic belief that are independent of de facto objections and that the Mādhva can demonstrate this through the resources contained with Madhva's religious epistemology, without needing to use Plantinga's epistemology. However, I leave it an open question whether or not de facto objections to Mādhvic belief can be successfully refuted.

\section{Outlining Madhva's epistemological framework}

I now turn my attention to Madhva's religious epistemology in order to demonstrate how it provides justification for belief in Viṣnu. First, it is important to note that within Madhva's epistemological framework, the two closest Sanskrit equivalents of the term 'knowledge', as it is defined in contemporary Anglophone contexts as a warranted true belief, are jũāna and pramāna. ${ }^{8}$ Jñanna can be roughly translated as 'awareness' or 'cognition'. The term pramāna, as Madhva uses it, is subdivided into kevalapramāna and anupramāna (Pramānalakșana ${ }^{10}$ ). Madhva defines kevalapramāna as the cognition of an 
object as it is', and anupramāna as 'the means of attaining [kevalapramāna]' (Pramānalakșana ${ }^{11}$ ). There are several sub-divisions of kevalapramāna; however, an extensive discussion of them is beyond the scope of this article. It suffices to say that the kevalapramanna of God (which is infallible) is superior to that of finite selves, and hence, selves must acquire kevalapramāna through the anupramānas, namely sense perception (pratyakșa), inferential reasoning (anumāna), and verbal testimony (which includes scriptural testimony) (ägama). It is verbal testimony that is particularly relevant for this article.

According to Madhva, ägama is a faultless verbal testimony (Pramānalakșaṇa ${ }^{12}$ ). Madhva defends the epistemic reliability of scripture by claiming that its prämānyam is on account of itself (svatah) (Visnutattvanirnaya ${ }^{13}$ ). The meaning of this statement depends on what we mean by prāmānyam. The term prāmānyam is derived from pramāna and can have one of two meanings. It can either refer to the epistemic property or properties (such as reliability or truth-conduciveness) of an anupramāna, on account of which this anupramāna can validate or certify cognitions. In this case, for scriptural testimony to be svatahprāmannya means that a cognition based on it is intrinsically reliable - it does not need its reliability validated by some other anupramanna. Or it can refer to the thing which, if possessed by an episode of jñanna, confers the status of kevalapramāna to a jñana. In this case, for scriptural testimony to be svatahprämānya means that when one cognizes scriptural texts, the prāmannya (that is, the thing that validates this cognition as being a kevalapramanna) is intrinsic to the cognition itself.

Madhva's defence of this claim is that if some epistemic instrument, let us say $\mathrm{X}_{1}$, were required to ensure the veridicality of the śruti texts, then $\mathrm{X}_{1}$ would require some other epistemic instrument, like $X_{2}$, to establish the accuracy of $X_{1}$. Consequently, $X_{2}$ would require another epistemic instrument, $X_{3}$, in order to validate it. This process will continue ad infinitum, thus requiring an infinite regress of epistemic instruments to demonstrate the veridicality of the śruti texts - a notion that Madhva finds untenable (Vișnutattvanirnaya $^{14}$ ). Presumably, Madhva, like many foundationalists, recognizes that such an infinite regress is problematic because finite selves cannot complete an infinite chain of reasoning. However, by declaring scriptural testimony to be svatahprāmannya and without need of further justification, Madhva is able to avoid such a regress in his epistemology.

Madhva's claim that scriptural testimony is svatahprämānya and requires no further justification from another epistemic source is similar to earlier formulations of Plantinga's epistemology, according to which, belief in God is properly basic and is not inferred from other beliefs. However, one problem with this view is that if our criterion for what constitutes a properly basic belief is too epistemically permissive, then a wide variety of irrational views, such as belief in the Great Pumpkin Monster, could be justified. One response the Mādhva can provide here is to assert that the teachings of scriptural texts can be intuited to be true on account of the cognitive faculty known as the säkșin, which will be discussed in greater depth shortly.

Moreover, an additional epistemological principle within Madhva's epistemology is the spiritual teacher, or guru, and more specifically, an apta-guru, or ideal spiritual teacher. Within his tradition, Madhva himself functions as an appta-guru, although it is also expected that individuals will receive spiritual instructions from a living guru who stands in an unbroken lineage of teachers that traces its heritage to Madhva himself.

Finally, provided that one's guru faithfully teaches Madhva's teachings, there is the question of how one can be sure that one is accurately interpreting these teachings. First, a student's guru can assess the student's grasp of Madhva's teachings and correct their understanding if required.

Moreover, one unique feature of Madhva's epistemological framework is the sākșin or the 'witness'. The sākșin is in truth the self, and it is often spoken about as if it is a 
cognitive faculty as well. The sākșin validates other cognitions, such as those acquired by the sense organs and the mind (Anuvyākhyāna 3.2.53 ${ }^{15}$ ). Madhva states that the validating judgements made by the sākșin do not themselves require successive validation, for the sākșin has a self-validating nature, because of which an infinite regress of further higherorder witnesses or judgements is not required (Anuvyākhyāna 3.2.53 ${ }^{16}$ ). In other words, if there were no cognitive facility such as the sākșin, each of our judgements would require an additional judgement, leading to the type of infinite regress that Madhva rejects. However, because the sākșin has a self-validating nature, such regresses have a termination point.

From Madhva's above reasoning, it can be implied that the following transcendental argument motivates his postulation of the sākșin.

1. If we would not have the sākșin, we would have an infinite regress of cognitive judgements.

2. We do not have an infinite regress of cognitive judgements.

Therefore, we have the sākșin.

Premise 1 is the most controversial premise of this argument. Although it can be argued that the postulation of the sākșin prevents the generation of an infinite regress of cognitive judgements, it is questionable whether or not the sākșin is required in order to terminate such a regress. Nevertheless, developing an epistemological framework that avoids an infinite regress is problematic for epistemologists even today, and Madhva's postulation of the sākșin is one novel attempt at a solution to this problem.

Madhva also states that the sākșin possesses various intuitive capacities. For instance, he states that it is because of the sākșin that we are also able to make broad generalizations about various objects and metaphysical categories ( padārtha) (Anuvyākhyāna 3.2.78). Moreover, according to Jayatīrtha ${ }^{17}$ (c. fourteenth century), it is the sākșin who intuits truths about supersensuous entities like the self's own form, the self's nature, ignorance, the mind, mental states, pleasure and pain, space, and time (Pramannapaddhati ${ }^{18}$ ). It is worth highlighting that the inherent intuitive capacities of the sākșin provide a reason for the Mādhva to believe that their intuitions track the truth. As Plantinga has famously argued, if naturalism is true, then it is doubtful that unguided evolutionary processes would lead us to acquire reliable cognitive faculties (Plantinga (1993b)). Although it is beyond the scope of this article to evaluate whether or not Plantinga's argument succeeds, it is worth noting that if Mādhvic belief is true, then our intuitions are likely to track the truth. This is because in Madhva's theological framework, the self is ontologically dependent on Vișnu, and thus the self's cognitive faculties are dependent on Viṣnu. It is also unlikely that Viṣnu would deceive us by endowing us with faulty cognitive capacities or by ontologically supporting such faulty faculties.

It is also important to point out that on account of the sākșin, our cognitive faculties that track metaphysical truths are not dependent on an infinite regress, since they are not dependent on an infinite series of cosmological cycles (the sākșin is inherent to the self and is hence not formed or produced on account of these cycles). Thus, although Madhva's ontological framework includes an actual infinite, there is no reason to conclude, as Baldwin and McNabb have, that Vișu's design plan for selves entails that their cognitive faculties are dependent on an actual infinite. For this reason, it is doubtful that Baldwin's and McNabb's argument that Mādhvas cannot avail themselves of Plantinga's epistemology succeeds in the first place.

Moreover, although the sense organs and the mind are imperfect epistemic instruments that can acquire misleading information about the world, the sākșin, according 
to Madhva, does not make incorrect judgements about the cognitions which it validates (Anuvyākhyāna 3.4.142 ${ }^{19}$ ).

A couple of examples can illustrate the workings of the sāksin. First, let us say that you correctly perceive that there is a tree in front of you. In this scenario, the tree in front of you is correctly perceived by your sense organs, your mind assembles this perceptual data and sends it to the sākșin, and the sākșin correctly judges that the tree was accurately perceived by the senses and that the mind correctly assembled this data. However, let us now say that you spot a shell in the distance and mistake it for silver. In this example, the shell is misapprehended by the sense organs and the mind, the mind relays this data (let us call this data D) to the sākșin, and the sākssin accurately judges that the mind is sending it D and not some other data $\mathrm{O}^{20}$

In the first example, the data collected by the mind and the sense organs was accurate, and the sākșin was correct in its judgement of this data, and hence, you correctly cognized that there was a tree in front of you. In the second example, the data D collected by the mind and the sense organs was not accurate. However, the sākșin correctly judged that the sense organs and the mind acquired D and not $\mathrm{O}$, though D itself was mistaken. In both scenarios, the verdict of the sākșin was accurate, and although you did not correctly perceive the shell in the second case, this failure to properly cognize the shell was due to the inability of the sense organs and the mind to acquire accurate data, and not because the sākșin failed to correctly validate this data. What these examples demonstrate is that in Madhva's epistemological framework, one can correctly cognize the objects of knowledge provided that the sense organs and mind deliver accurate data to the sākșin. Hence, it can be inferred that if a self is presented with accurate information about God, they will be able to properly cognize these truths on account of the sākșin.

Madhva's epistemological framework can now be summarized as follows. Scriptural testimony provides authoritative information about God. The teachings are assimilated by gurus and passed down from guru to student in a chain of tutelary succession to the present day. The student is then able to properly cognize these truths on account of the sākșin. I will henceforth refer to this epistemological chain as the Mādhva epistemological chain (MEC). Through the MEC, selves can acquire a mediated cognition (parokșa-jñana) of God, that is, a cognition of Viṣnu that is mediated by the MEC. Through the performance of bhakti, individuals can also attain an unmediated cognition (aparokșa-jñāna) of Vișnu in which they perceive Vișnu directly. However, since this latter cognition is rarer and is best treated as the focal point for an argument from experience, I restrict my discussion to parokșa-jñāna.

Moreover, I argue that Madhva's religious epistemology is structured by an internalist account of warrant insofar as religious knowledge is concerned. ${ }^{21}$ This is because the Mādhva has access to properties which confer justification (these will be elaborated upon shortly).

From these points, we can formulate the following argument in the context of Mādhva Vedānta:

1. One is justified in believing a source of knowledge that provides unerring kevala-pramāna.

2. The MEC provides unerring kevala-pramāna about Vișnu.

3. The MEC informs us that Viṣnu exists.

Therefore, one is justified in believing that Viṣnu exists.

I take premises (1) and (3) to be uncontroversial. The soundness of this argument thus depends on whether or not (2) is true. It is important to note, however, that if Mādhvic belief is true, then (2) is true, and one is justified in believing that Viṣnu exists. For this 
reason, I argue that provided that the Mādhva is justified in believing (2), there are no de jure objections to Mādhvic belief that are independent of de facto objections.

We may now ask ourselves what justification a Mādhva has for accepting the teachings of the MEC. There are various options available here to the Mādhva. The first option is to invoke an epistemological principle similar to Richard Swinburne's Principle of Testimony (Swinburne (2004), 322). Such is a principle is as follows:

Mādhvic Principle of Testimony (MPT): In the absence of special considerations or defeaters, the testimony of a trustworthy spiritual authority is reliable insofar as supramundane truths are concerned.

Such a principle might be defended as follows. A trustworthy spiritual authority is one who has perceived supramundane truths contained in scriptural texts through their experience (in other words, they have aparokșa-jñāna). Since such an authority would not be desirous of deceiving others, the Mādhva is prima facie justified in believing their teachings. The Mādhva can add that a denial of the reliability of testimony could have devastating sceptical consequences - much of our knowledge is acquired through testimony, and if we were to treat such knowledge as being epistemologically suspect until further proof is given, we would be forced to remain sceptical about much of what we know.

The caveat to this principle is that we require the ability to distinguish between a reliable spiritual authority and an unreliable spiritual authority. However, the Mādhva tradition provides criteria by which this distinction can be made (see Sarma (2015)).

Additionally, the Mādhva may (a) via the sākșin intuit that the truths of scriptural texts are self-evident (in the same manner that it is self-evident that torturing babies for fun is wrong) and do not require additional justification. Or, one may (b) find that their religious experiences cohere with Madhva's teachings and hence support them. Yet, one could challenge either of these reasons. Since a discussion of the epistemological significance of religious experience within the Mādhva tradition is beyond the scope of this article, I will focus on (a). One obvious objection to (a) is that intuitions can be misleading and do not always correspond to reality (such as when a gambler intuits that his next gamble will be successful and it turns out not to be). However, Mādhvas can respond to this objection by noting that an outright denial of intuition leads to radical scepticism about many important views that we take to be rational. For instance, for most people, belief that the external world is real and that we are not brains in a vat that are being manipulated by an evil scientist who wants us to think that the external world is real, is ascertained by our intuitions and not by any empirical evidence or sound argumentative reasoning. Any empirical evidence we can gather would be inconclusive for determining the truth value of this belief - the world could appear the same whether it is actually real or an illusion conjured by the evil scientist. Arguments also fail to prove the thesis of external world realism over the brain-in-a-vat thesis - conclusively ascertaining the truth of one of these theses over the other is simply beyond the scope of logic and reasoning when the phenomenal content of our experiences supports either thesis.

In a similar manner, as Plantinga argued, the belief that other humans have minds like our own is also a belief that cannot be determined by empirical evidence or arguments (Plantinga (1967)). Though we can offer arguments in favour of the thesis that our humans have minds like our own, these arguments are insufficient to draw any definitive conclusion about the mental states of other humans. Yet, we are inclined to believe that other humans indeed have minds like our own in spite of lacking sufficient evidence to prove this claim. The Mādhva can point out that here, the belief that other humans have minds is formed on the basis of intuition. 
Moreover, if one tries to employ abductive reasoning in order to infer that external world realism is a better hypothesis than the brain-in-a-vat thesis, they must assume that our ability to reason about truths that are within our epistemic reach (such as descriptions of the observable world) entails that we can employ abductive reasoning to reliably draw conclusions about truths that are not within our epistemic reach (such as whether or not we are a brain in a vat). However, in order to make this assumption, we must beg the question against the brain-in-a-vat thesis, for such an assumption only holds if this thesis is false.

Hence, if one's epistemological framework is too restrictive in the epistemic reliability it affords intuition, this framework cannot avoid radical scepticism about many important beliefs. At the same time, it is still true that intuitions are not always reliable, and hence an epistemological framework that affords intuition too much epistemic reliability can lead to the acquisition of many false beliefs.

Yet, the Mādhva can draw upon their epistemological resources to put forth the following epistemological principle that is arguably neither too restrictive nor too permissive in terms of the epistemic reliability it grants intuition:

Principle of Justified Intuition (PJI): if an agent has the epistemic virtues needed to intuit the truth of a proposition $\mathrm{P}$, and $\mathrm{P}$ coheres with other established facts, they are prima facie justified in believing their intuition that $\mathrm{P}$, and ultima facie justified in believing their intuition that $\mathrm{P}$ in the absence of defeaters.

According to the PJI, when an individual intuits the truth of Madhva's teachings, they are prima facie justified in holding the belief that they are true. They can also argue that the reason that others are not able to intuit the truth of Madhva's teachings is because they lack the epistemic virtues needed to intuit their truth, and not because the truth of these teachings is not self-evidently true. ${ }^{22}$ Thus, the Mādhvā can have justification for their belief in the reliability of Madhva's teachings.

\section{Addressing objections}

I will now address various objections to Madhva's religious epistemology. First, since Madhva's religious epistemology is structured by an internalist account of justification, it is subject to Bergmann's dilemma for internalism. To understand this dilemma, some clarification of terms is in order. When an agent can conceive of the thing that contributes to them having justification for a belief, such awareness is called strong awareness. When the agent cannot conceive of this justification-contributor, this awareness is called weak awareness (Bergmann (2006), 13). Moreover, the Subject's Perspective Objection (SPO) states, 'if the subject holding a belief isn't aware of what that belief has going for it, then she isn't aware of how its status is any different from a stray hunch or an arbitrary conviction. From that we may conclude that from her perspective it is an accident that her belief is true. And that implies that it isn't a justified belief' (ibid., 12). With these terms in place, we can now make sense of Bergmann's dilemma for internalism, which in his own words is formulated in the following argument:

1. An essential feature of internalism is that it makes a subject's actual or potential awareness of some justification-contributor a necessary condition for the justification of any belief held by that subject.

2. The awareness required by internalism is either strong awareness or weak awareness.

3. If the awareness required by internalism is strong awareness, then internalism has vicious regress problems leading to radical scepticism. 
4. If the awareness required by internalism is weak awareness, then internalism is vulnerable to the SPO, in which case internalism loses its main motivation for imposing the awareness requirement.

5. If internalism either leads to radical scepticism or loses its main motivation for imposing the awareness requirement (i.e. avoiding the SPO), then we should not endorse internalism.

Therefore, we should not endorse internalism. (ibid., 13-14)

The crux of this argument is this. If the awareness for internalism is strong awareness, then agents need to be aware of each justification-contributor for their beliefs. However, each justification-contributor also requires a justification-contributor, and hence, one would require an infinite regress of justification-contributors for each justification. Since an infinite regress of justification-contributors is, presumably, impossible, radical scepticism follows, since it would seem that we could hardly know anything at all.

Yet, if the awareness required for internalism is weak awareness, then internalism is subject to the SPO, which is the main reason for endorsing internalism. Hence, whether one requires strong awareness or weak awareness for internalism, it seems that one should not endorse internalism.

However, I argue that the Mādhva has a way out of Bergmann's dilemma. The first response that the Mādhva can provide is that on account of the sākșin, each justification has a finite number of justification-contributors, because the sākșin, on account of its selfvalidating nature, requires no further justification or validations for its judgements. To see how the concept of the sāksin resolves the issue of an infinite regress in this manner, let us first imagine that the sākșin is non-existent. Let us also say that you see smoke on a mountain and conclude that there is a fire on the mountain. Your reason for believing that there is fire on the mountain is because you believe that wherever there is smoke, there is fire. You believe this inductive statement because every time you have seen smoke, you have seen fire. Your belief in this generalization is based on your belief that you have the ability to make correct inferences. Yet, how would you know that you make correct inferences? You need a reason $R_{1}$ to believe that you make correct inferences. However, you need another reason $\mathrm{R}_{2}$ for why you believe $\mathrm{R}_{1}$ and so on ad infinitum.

Now, let us imagine this same scenario, but this time, let us posit the existence of the sākșin. When the chain of justification-contributors arrives at the point of you needing a belief to justify your ability to make correct inferences, your reason $\mathrm{R}_{1}$ for believing that you make correct inferences can be because you are aware that the sākșin has the ability to correctly infer beliefs. Yet, your reason $R_{2}$ for believing $R_{1}$ can simply be because the $s \bar{a} k s i n$ has a self-validating nature that does not require additional justifications for its judgements. You do not require an additional reason $R_{3}$ for believing $R_{2}$ - within Madhva's epistemological framework $\mathrm{R}_{2}$ is simply a self-evident state of affairs that does not require additional justification, and notably, Madhva eschews the need for this additional justification precisely because it leads to the type of infinite regress that Bergmann himself describes.

However, the crucial question is, how can one acquire justification for the sākșin? If one's justification for the sākșin requires strong awareness, then one has not avoided an infinite regress, for this justification requires a justification-contributor, which itself requires a justification-contributor, and so on ad infinitum. Yet, if the justification for the sākșin requires weak awareness, then one is vulnerable to the SPO.

The Mādhva can justify their belief in the sākșin as follows. They can (1) accept the existence of the sākșin based on the MPT, (2) see that they have accurate intuitions about metaphysical truths and assess that this is likely if we have a cognitive mechanism like the sākșin and less likely if naturalism is true and we do not have such a mechanism, 
(3) reflect on their mental states and acquire grounds for thinking that there is some cognitive mechanism that validates their mental states that is above and beyond the mind, and (4) do a combination of (1)-(3).

In the case of (1), one requires some justification for accepting the MPT. The most obvious justification is that what people tell us is generally reliable and accurate. However, this raises the question: when a person tells us some fact $\mathrm{X}$, how do we know that $\mathrm{X}$ is true? One could try to verify $X$ through perception. However, doing so requires that they use their senses and that their senses are reliable. Either (a) one is strongly aware of their justification for thinking that their senses are reliable, or (b) one is weakly aware of their justification for thinking that their senses are reliable. However, this set of disjunctive choices leads to Bergmann's dilemma.

In fact, in the case of (2), one does not escape the dilemma either, for one is either weakly aware or strongly aware that their intuitions about metaphysical truths are accurate. In the case of (3), one has to be aware of (i) one's mental states, (ii) the fact that there is some cognitive mechanism that validates their mental states, and (iii) their reason for thinking that (i) and (ii) provide justification for belief in the sākșin. The awareness of (i), (ii), and (iii) involves either weak awareness, strong awareness, or a combination of the two. Thus, Bergmann's dilemma remains problematic in the case of (2) and (3) as well.

I believe that the most promising option for the Mâdhva who wants to escape Bergmann's dilemma is to avail themselves of insights from contemporary epistemologists. In cases (1), (2), and (3), the Mādhva can assert that they have an awareness of the relevant facts through direct acquaintance, which occurs when a person is acquainted with an object by standing in a direct cognitive relationship to it (Russell (1910)). As John DePoe states, 'direct acquaintance is a kind of awareness that is unmediated, noninferential, and does not involve the application of any concepts' (DePoe (2012), 419). Following Richard Fumerton (1995, 73-79), DePoe states that an individual has noninferential justification for believing a proposition $\mathrm{P}$ when they are directly acquainted with the fact that $\mathrm{P}$, directly acquainted with the thought that $\mathrm{P}$, and directly acquainted with the correspondence that holds between the fact that $\mathrm{P}$ and the thought that $\mathrm{P}$ (DePoe (2012), 420).

In the case of (1), the Mādhva can be directly acquainted with the fact that their senses are reliable, directly acquainted with the thought that their senses are reliable, and directly acquainted with the correspondence that holds between this fact and this thought. In the case of (2), the Mādhva can be directly acquainted with the fact that their intuitions about metaphysical truths are reliable, directly acquainted with the thought that their metaphysical intuitions are reliable, and directly acquainted with the correspondence that holds between this fact and this thought. By now, we can see how the Mãdhva can justify their belief in (i)-(iii) in the case of (3).

However, the crucial question in all these cases is whether or not strong awareness of this correspondence is required. If it is, then the problem of infinite regresses has not been solved. If it is not, then the Mādhva remains exposed to the SPO. Nevertheless, the Mādhva, following DePoe, can maintain that only a weak awareness of this correspondence is required and that such weak awareness is far from being the type of stray hunch or arbitrary conviction that Bergmann describes when defining the SPO (DePoe (2012), 421).

Once the Mādhva has established the existence of the sākșin, then they can justify their theistic belief through either the MPT (in case they did not previously justify their belief in the MPT according to the reasoning above) or the PJI. In either case, the Mādhva has an internally accessible reason for their theistic belief.

Since the Mādhva is able to justify their belief in Madhva's teachings, while also circumventing Bergmann's dilemma, I argue that if an objector to Mādhvic belief wants 
to raise a de jure objection against this belief, then they must directly object to the reliability of all the components of the MEC. However, if the objector objects to the reliability of the MEC, I argue that they must put forth a de facto objection to the reliability of at least one link in the MEC. Hence, I conclude that there are no de jure objections to Mādhvic belief that are independent of de facto objections.

\section{Conclusion}

In this article, I have argued that there are no de jure objections to Mādhvic belief that are independent of de facto objections. Though there are objections that can be raised against Madhva's epistemological framework on account of it being structured by an internalist theory of warrant with respect to religious knowledge, I have demonstrated that this framework has the resources needed to respond to these objections.

However, I have not addressed the question of whether de facto objections to Mādhvic belief can be successfully refuted. I leave this an open question. Yet, even if it turns out that de facto objections to Mādhvic belief are too devastating to refute, this would only show that that are issues with Madhva's theology but not necessarily his religious epistemology.

It is worth adding that if other religious traditions accept scriptural testimony, have a lineage of gurus, and posit the existence of some cognitive mechanism analogous to the sāksin, they can justify their theistic beliefs along similar lines of reasoning as those that I have advanced in this article. For instance, the Caitanya Vaisnava tradition, whose theologians have posited the existence of a faculty of intuition that is inherent to the self (Ghosh (2019)), may be one such tradition.

of course, these traditions would still have to address de facto objections. However, if these traditions can successively refute such objections, Plantingian epistemology would have some new contenders.

\section{Notes}

1. Vaiṣnavas are devotees of the deity Vișnu, or, in certain contexts, Krș̣na.

2. Henceforth, when I speak of selves, I refer to finite selves and not to the Supreme Self.

3. Brahman is the closest Sanskrit equivalent to 'God'.

4. Individuals within the Mādhva tradition.

5. Belief in God as God is envisioned within the Mādhva tradition. I take this to mean belief in the core doctrinal tenets of the Mādhva tradition. I also assume that encompassed within Mādhvic belief is the idea that one's guru is a reliable authority about Madhva's teachings. Hence, if Mādhvic belief is true, then one's guru would be a reliable authority about Madhva's teachings.

6. There are various types of defeaters, but broadly understood, a defeater is a reason for you to have less confidence in a belief B. Defeaters can also be defeated by other defeaters.

7. For instance, Plantinga denies that beliefs that are considered absurd, such as belief that the earth is flat and belief in Voodoo, are rational since they are not warranted-if-true (Plantinga (2000), 174).

8. Of these two terms, pramanna is the closest Sanskrit equivalent to knowledge.

9. As I will later indicate, Mādhvas can have a mediated cognition (parokșa-jñāna) or unmediated cognition (aparokșa-jñāna) of God.

10. tad dvividham | kevalam anupramānam ca | 'There are two types [of prāmaṇas]: kevalaprāmaṇa and anuprāmaṇa' (cited from Sarma (2016), 21; verse numbers for the Pramānalakșaṇa are not specified).

11. yathärthajñānaṃ kevalam | tatsādhanam anupramānam | 'Kevalaprämana is an awareness of an object as it is. The means of attaining that [kevalapramāna] is anupramāna' (ibid.).

12. nirdoșah śabda āgamah | 'Āgama is a verbal testimony without faults' (ibid., 24).

13. prāmānyam ca svata eva | The prāmannya [of scriptural testimony] is on account of itself (ibid., 35).

14. anyathānavasthānāt | 'Because otherwise there would be an infinite regress' (ibid.). 
15. sākșipratyakșato hy eva mānānām mānateyate | 'Indeed, the ability of the pramānas to measure (i.e. produce kevalapramāna) occurs because of the perceptions of the sākșin.' All references to the Anuvyākhyāna are from http://gretil.sub.uni-goettingen.de/gretil/corpustei/transformations/html/sa_mAdhva-anuvyAkhyAna.htm.

16. sākșinah svaprakāśatvam anavasthā tato na hi| 'There is no infinite regress in relation to the sākșin because of its self-illuminating nature.'

17. Next to Madhva, Jayatīrtha is perhaps the most important exegete-theologian within the Mādhva tradition.

18. tasya vișayāh ātmasvarūpaṃ tad-dharmā avidyā manaḥ tad-vṛttayo bāhyendriya-jñāna-sukhādyāḥ kālo 'vyākțākāśaś ca ity ādyāh | 'The sākșin's objects of perception are the self's own form, the self's nature, ignorance, the mind, mental states, the outer senses, awareness, pleasure and so on, and time and space' (unspecified verse; cited from Sharma (1986), 184).

19. manase darśane doșah syur na vai sākșidarśane |'There may be faults in the cognitions of the mind, but not in the cognitions of the sāksin.'

20. It is worth noting that theories of perceptual illusions were developed by Madhva and then later Jayatirtha. Although it is beyond the scope of this article to discuss them in length, the reader can consult Williams (2017) for a comprehensive overview of them. In brief, according to Jayatirtha, misidentification is a 'cognition that takes one thing for its form, while having something else for its object' (Nyāyasudhā; Kațti (1982), 645 cited in Williams (2017), 569).

21. Within Madhva's epistemological framework, perceptual knowledge is acquired via a reliable belief-forming process, namely, perception ( pratyakșa), without a requirement that one internally access their reasons for belief. Hence, I am reluctant to describe Madhva's epistemology solely in terms of internalism or externalism because each of the anupramānas within Madhva's epistemology has its own epistemological parameters.

22. Within Vedāntic discourse, it is common for a Vedāntic tradition to stipulate certain conditions that a spiritual practitioner must meet if they are to possess the requisite eligibility (adhikāra) in order to realize (and not merely acquire an academic understanding of) the import of scriptural texts. For instance, Madhva writes that a spiritual practitioner in his tradition should be devoted to their guru and possess qualities such as evenness of mind (Brahmasūtrabhāṣya 3.4.12; Prabhanjanacarya (1999), 223).

\section{References}

Baldwin E and McNabb TD (2018) Plantingian Religious Epistemology and World Religions: Prospects and Problems. New York: Lexington Books.

Bergmann M (2006) Justification Without Awareness: A Defense of Epistemic Externalism. Oxford: Oxford University Press.

Depoe JM (2012) Bergmann's dilemma and internalism's escape. Acta Analytica 27, 409-423.

Fumerton R (1995) Metaepistemology and Skepticism. Lanham: Rowman \& Littlefield.

Gettier EL (1963) Is justified true belief knowledge? Analysis 23, 121-123.

Ghosh A (2019) Innate intuition: An intellectual history of sahaja-jñāna and sahaja samādhi in Brahmoism and modern Vaiṣnavism. Religions 10, 384.

Kațți R (ed.) (1982) The Nectar of Reasoning (Nyāyasudhā). Bangalore: Sudhāmudraṇamandiram.

McNabb TD and Baldwin E (2016) Reformed epistemology and the Pandora's Box objection. Philosophia Christi 18, 451-465.

Plantinga A (1967) God and Other Minds. Ithaca: Cornell University Press.

Plantinga A (1993a) Warrant: The Current Debate. Oxford: Oxford University Press.

Plantinga A (1993b) Warrant and Proper Function. Oxford: Oxford University Press.

Plantinga A (2000) Warranted Christian belief. Oxford: Oxford University Press.

Prabhanjanacarya V (1999) Sarvamūlagranthaḥ: Collected Works of Śrī Madhwācārya, 7 Volumes, vol. 1. Bangalore: Śrī Vyāsamādhawa Sevā Pratișthāna.

Russell B (1910) Knowledge by acquaintance and knowledge by description. Proceedings of the Aristotelian Society $11,108-128$.

Sarma D (2015) The Āptaguru. International Journal of Hindu Studies 19, 193-212.

Sarma D (2016) An Introduction to Mādhva Vedānta. London: Routledge.

Sharma BNK (1986) Philosophy of Śrī Madhvācārya Revised Edition. Delhi: Motilal Banarsidass.

Swinburne R (2004) The Existence of God. Oxford: Oxford University Press.

Williams M (2017) Jayatīrtha and the problem of perceptual illusion. In Ganeri J (ed.), The Oxford Handbook of Indian Philosophy. Oxford: Oxford University Press, pp. 559-576.

Cite this article: Gupta A (2022). Are there de jure objections to Mādhvic belief? Religious Studies 58, 732-744. https://doi.org/10.1017/S0034412521000251 